\title{
Utilization of Industrial Waste Perlite Powder and Vermiculite in Self Compacting Concrete
}

\author{
Dr. P. Muthupriya* \\ *Professor \& Head \\ Department of Civil Engineering, \\ Dr. N.G.P. IT, CBE -48
}

\author{
K. S. Shobana \\ Assistant Professor, \\ Department of Civil Engineering, \\ Dr. N.G.P. IT, CBE - 48
}

\begin{abstract}
Self-Compacting Concrete is an innovative concrete that does not require vibration for placing and compaction. It is able to flow under its own weight, completely filling formwork and achieving full compaction, even in the presence of congested reinforcement. In this investigation, the workability of partially replacing industrial waste perlite powder and vermiculite in SCC is studied and there characteristic is compared.The mix proportion is obtained as per the guidelines given by European Federation of producers and contractors of specialist's products for structure (EFNARC). SCC mixes are produced by replacing the cement with $5 \%, 10 \%, 15 \%$ of industrial waste perlite powder and replacing the fine aggregate with $5 \%, 10 \%, 15 \%$ of vermiculite. The w/c ratio used in this investigation is 0.35 . Super Plasticizer used in this study is CONPLAST SP430 and its dosage is $0.5 \%$ to obtain the required SCC mix. Fresh concrete properties are checked by conducting the workability tests such as Slump Flow, T 50 Slump Flow, LBox, U-Box, V- Funnel, V-Funnel T5 minutes, and J- Ring tests. In this investigation, the workability of partially replacing industrial waste perlite powder and vermiculite in SCC is studied and there characteristic is compared. SCC is a kind of concrete that can flow through and fill gaps of reinforcement and corners of moulds without any needs for vibration and compacting during the pouring process. The mix proportion is obtained as per the guidelines given by European Federation of producers and contractors of specialist's products for structure (EFNARC). SCC mixes are produced by replacing the cement with $5 \%, 10 \%, 15 \%$ of industrial waste perlite powder and replacing the fine aggregate with $5 \%, 10 \%, 15 \%$ of vermiculite. The w/c ratio used in this investigation is 0.35. Super Plasticizer used in this study is CONPLAST SP430 and its dosage is $0.5 \%$ to obtain the required $\mathrm{SCC}$ mix.

Fresh concrete properties are checked by conducting the workability tests such as Slump Flow, T 50 Slump Flow, LBox, U-Box, V- Funnel and J- Ring tests. This project has been devoted to investigate and compare the workability nature of conventional concrete with SCC.
\end{abstract}

Keywords: Self-compacting concrete, perlite, vermiculite,

\section{INTRODUCTION}

Concrete is a widely used construction material around the world, and its properties have been undergoing changes through technological advancement. The earliest is the traditional normal strength concrete which is composed of only four constituent materials, which are cement, water, fine and coarse aggregates. With a fast population growth and a higher demand for housing infrastructure, accompanied by recent developments in Civil Engineering, such as high-rise buildings and long-span bridges, higher compressive strength concrete was needed. At the beginning, reducing the water-cement ratio was the easiest way to achieve the high compressive strength. Thereafter, the fifth ingredient, a water reducing agent or super plasticizer, was indispensable. The chemical admixture is said to be any material that is added in a small quantity (i.e., less than $5 \%$ ) to the concrete mixture which enhances the properties of concrete in both the fresh and hardened state. In recent years, the usage of self-compacting concrete in ready mix concrete plants have tremendously increased due to its advantages in consolidation, uniformity and reliability. Self-compacting Concrete is an innovative concrete that does not require any vibration for placing and compaction. It is able to flow under its own weight, completely filling formwork and achieving full compaction, even in the presence of congested reinforcement. Self-Compacting Concrete is a complex system that is usually proportioned with one or more additions and one or more chemical admixtures. A key factor for a successful formulation is a clear understanding of the role of the various constituents in the mix and their effects on the fresh and hardened properties. Successful self-compacting concrete must have high fluidity (for flow under self-weight), high segregation resistance (to maintain uniformity during flow) and sufficient passing ability so that it can flow through and around reinforcement without blocking or segregating. Superplasticizers added to concrete provide a better workability. One of the disadvantages of self- compacting concrete is its cost, associated with the use of chemical admixtures and use of high volumes of Portland cement. The water demand and workability are controlled by particle shape, particle size distribution, particle packing effects and the smoothness of the surface texture. One alternative to reduce the cost of self-compacting concrete is the use of additions. More recently, environmental arguments began to prevail, in particular the need to decrease the overall $\mathrm{CO} 2$ production related to the use of cement in concrete. The lower water content of the concrete leads to higher durability, in addition to better mechanical integrity of the structure. Vermiculite and perlite may improve rheological properties and reduce thermally-induced cracking of concrete due to the reduction in the overall heat of hydration and increase the workability and long-term properties of concrete. One of the most important differences between self-compacting concrete and conventional concrete is the incorporation of perlite and vermiculite. Since cement is one of the most expensive components of concrete, reducing the cement 
content is one of the economical solutions. Besides these economical benefits, the use of byproducts or waste materials reduces environmental pollution.Howeverwith self-compacting concrete the water/ powder ratio has to be chosen by taking self-compactability into account, since self-compatibility is very sensitive to this ratio. The next important aspect in achieving Self compaction is cementsuper plasticizer compatibility. Superplasticizers mainly based on steric repulsive forces include polycarboxylate based agents. They have a molecular structure composed of a backbone of a long straight chain of carbon atoms with side ethylene oxide chains which absorb water and produce a thick layer on the cement surface, thus generating effective steric repulsion. In addition, the carboxyl group in the molecule also gives a negative charge to cement particles, thus providing some electrostatic particle repulsion. In terms of cost today polycarboxylic ether and sulphanated melamine formaldehyde are used equal (taken on an effective solids basis),sulphanatedmelamine formaldehyde is about half the cost of polycarboxylic ether, while lignosulphonate is the cheapest (about one fourth cost of Polycarboxylic ether). However, in the terms of effectiveness to achieve a specific workability of concrete, the amount of polycarboxylic ether required is significantly lesser than of lignosulphanate. Polycar- boxylate are the most effective of all the chemicals used in concrete. The admixture cancause a reduction in water content of as much as $40 \%$. Generally this chemical exhibit good slump retention characteristic and do not cause any delay in the gain of strength of concrete. Polycarboxylic ether can work at lower dosage than lignosulphonate. The newly developed Polycarboxylic ether based super plasticizer is able to provide high consistence, proper viscosity and long consistence retention even in a small amount and at low Water/Powder ratio. It is therefore especially suitable for self- compacting concrete and is the most commonly used. In this study, it is aimed to investigate the effect of perlite and vermiculite on the fresh properties of Self-Compacting Concrete. Fresh concrete tests such as slump-flow, L- box, T50 slump flow, U-box, V-funnel,V-funnel T5 minutes and J-ring test were conducted.However working on the parameters which affect the basic properties of SCC Such plastic viscosity, deformability, flow ability and resistance to segregation, SCC may be proportioned for almost any type concrete structure. To establish an appropriate mixer proportion for a SCC the performance requirements must be defined taking into account the structural conditions such as shape, dimensions, reinforcement density and construction conditions. The construction conditions include methods of transporting, placing, finishing and curing. The specific requirement of SCC is its capacity for self-compaction, without vibration, in the fresh state.

\section{SELF COMPACTION CONCRETE}

\section{A) Definition}

The concrete that is capable of self consolidation and occupying all the formwork without any vibration is termed as selfcompaction concrete. The guiding principle behind the self - compaction is that the sedimentation velocity of a particle is inversely proportional to the viscosity of the floating medium in which the particle exists.

\section{B)Investigation on materials}

The materials used for the concrete mix are

1. Ordinary Portland Cement (53 grade)(confirming to IS 8112)

2. Potable water

3. Industrialwaste perlite powder

4. Coarse aggregate $(10 \mathrm{~mm})$

5. M-sand

6. Vermiculite

7. Superplasticizer (CONPLAST SP430)

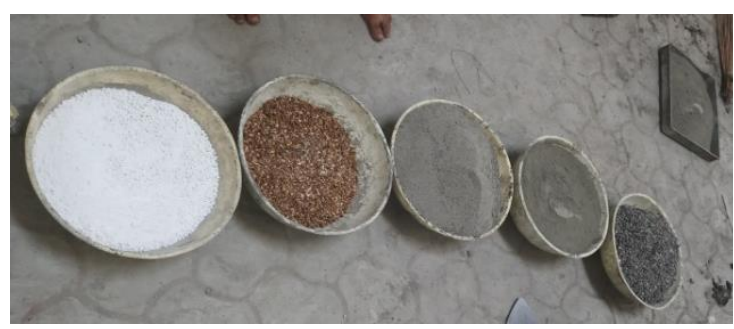

Fig. 1 Materials used

\section{1) Cement}

Ordinary Portland cement (53 grade) cement conforming to IS 8112 was used. The various laboratory tests were conducted on cement to determine standard consistency, initial and final setting time as per IS 403 I and IS $269-$ 1967. The results are tabulated in table 1 the result conforms to the IS recommendations

TABLE - 1 PROPERTIES OF CEMENT

\begin{tabular}{|l|l|l|}
\hline S.No & Test conducted & Result \\
\hline 1. & Normal consistency & $32 \%$ \\
\hline 2. & Initial setting time & 30 minutes \\
\hline 3. & Final setting time & 540 minutes \\
\hline 4. & Specific gravity of cement & 3.15 \\
\hline
\end{tabular}

\section{2)Potable water}

Water is the most important ingredient in concrete mix as it actively participates in chemical reactions with cement to form hydration product (CSH gel). The higher the water binder ratio, more the strength, durability and water tightness. The mixing water should be fresh, clean and potable. The water should be relatively free from organic matter, silt, oil, sugar, chloride and acidic material. It should have a $\mathrm{PH} \geq 7$ to minimize the reduction in the $\mathrm{PH}$ of the mortar slurry. Salt water is not acceptable, but chlorinated drinking water can be used.Potable water as per IS:456 2000 is used for the mix.

\section{3) Industrial waste Perlite powder}

Perlite is a material ofvolcanic origin. It is thermally treated in order to obtain its expanded form, which has several advantageous properties such as low thermal conductivity and a high ability of absorbing liquids and gases in combination with low density. Expanded perlite is 
commonly used as a component of lightweight concretes and heat-insulating plasters and mortars as well as various types of thermal and acoustic insulations. However, during the treatment of natural perlite, a large amount $(5 \%-10 \%$ of the product) of powder is created. Industrial waste perlite powder which consists mainly of silica (72-75\%) and $\mathrm{Al} 203$ (12-15\%) is commonly light grey or white colour.

\section{4)Coarse aggregate}

The shape and particle size distribution of the aggregate is very important as it affects the packing and voids content. The moisture content, water absorption, grading and variations in fine content of all aggregates should be closely and continuously monitored and must be taken in to account in order to produce SCC of constant quality. Coarse aggregate used in this study had a maximum size of $12.5 \mathrm{~mm}$. Properties of the coarse aggregateused in the experimental work are tabulated in table 2 .

TABLE - 2 PROPERTIES OF COARSE AGGREGATE

\begin{tabular}{|l|l|l|}
\hline SI.No & Test conducted & Result \\
\hline 1. & Specific gravity & 2.85 \\
\hline 2. & Fineness modulus & $7.71 \%$ \\
\hline
\end{tabular}

\section{5) Fine aggregate}

The sand used for experimental program was locally procured and conforming to zone II. The sand was first sieved through $4.75 \mathrm{~mm}$ to remove and particles greater than $4.75 \mathrm{~mm}$. the fine aggregates were tested as per Indian standard specification IS:383 - 1970. Properties of the fine aggregate used in the experimental work are tabulated in table 3 .

Table-3 Properties of Fine Aggregate

\begin{tabular}{|l|l|l|}
\hline S.No & Test conducted & Result \\
\hline 1. & Specific gravity & 2.68 \\
\hline 2. & Fineness modulus & $6.17 \%$ \\
\hline
\end{tabular}

\section{6) Vermiculite}

The Vermiculite is used as a filler material and it is obtainable in golden brown, can also be white, colourless or yellow. The specific gravity of vermiculite is 2 . Property of the vermiculite used in the experimental work is tabulated in table 4.

\begin{tabular}{|l|l|l|}
\hline S.No & Test conducted & Result \\
\hline 1. & Specific gravity & 2.0 \\
\hline
\end{tabular}

\section{7)Chemical admixture}

Super plasticizer CONPLAST SP 430 was used for mixing. In order to achieve flow ability in self compacting concrete, water content has not to be increased since it will cause segregation and bleeding instead super plasticizer has to be added. CONPLAST SP 430 will increase the strength of the concrete. Very high content of super plasticizer can affect the process of hydration.

\section{8)Mix proportion}

Cement $=416 \mathrm{~kg} / \mathrm{m} 3$

Fine aggregate $\quad=1046 \mathrm{~kg} / \mathrm{m} 3$

Coarse aggregate $=926 \mathrm{~kg} / \mathrm{m} 3$

Water $=145.68$ liter

Super plasticizer $=0.5 \%$

Mix proportion $=1: 2.5: 2.2$

\section{A) Fresh state Tests:}

Tested on fresh concrete were performed to study the workability of SCC with various proportions of perlite and vermiculite. The tests conducted are listed below.

- Slump flow test

- V- funnel test

- J- ring test

- L- box test

- U- box test

1)V-funnel test

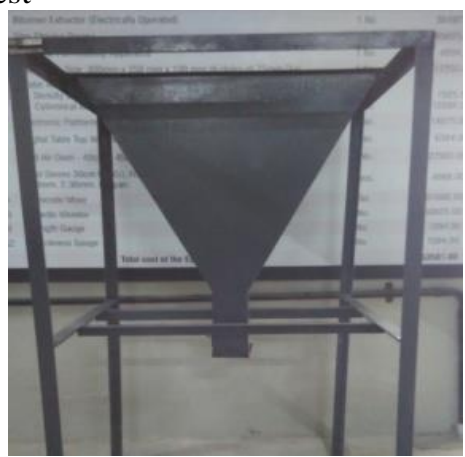

Fig. 2 V - Funnel Apparatus

2) J -ring test

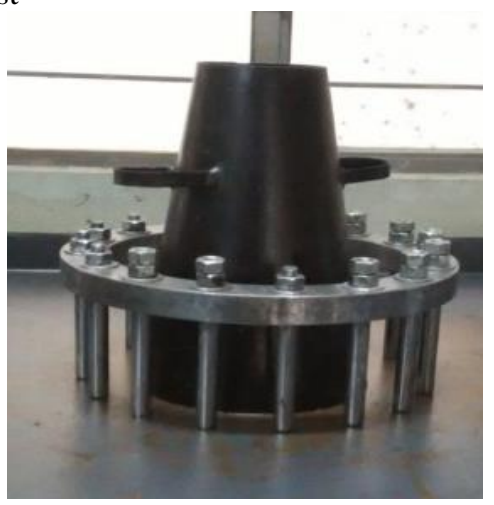

Fig. $3 \mathrm{~J}$-ring Apparatus

3) U-box test

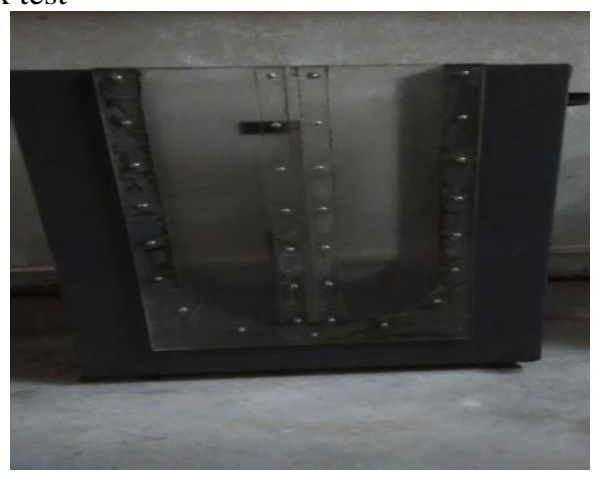

Fig. 4 U-box Apparatus 
4) slump flow test

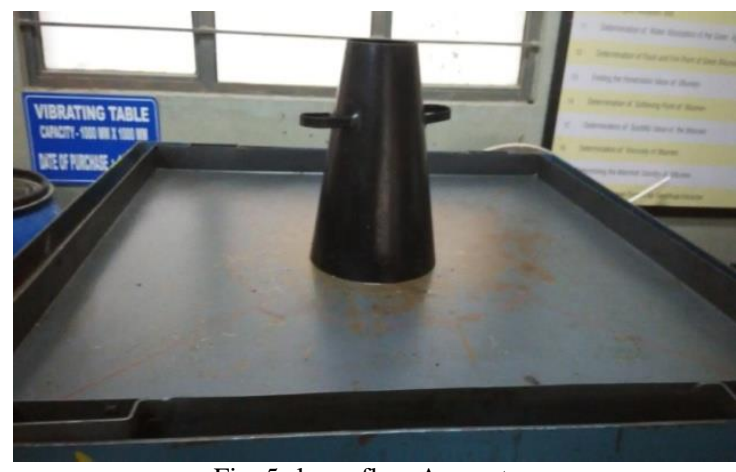

Fig. 5 slump flow Apparatus
5)L- box test

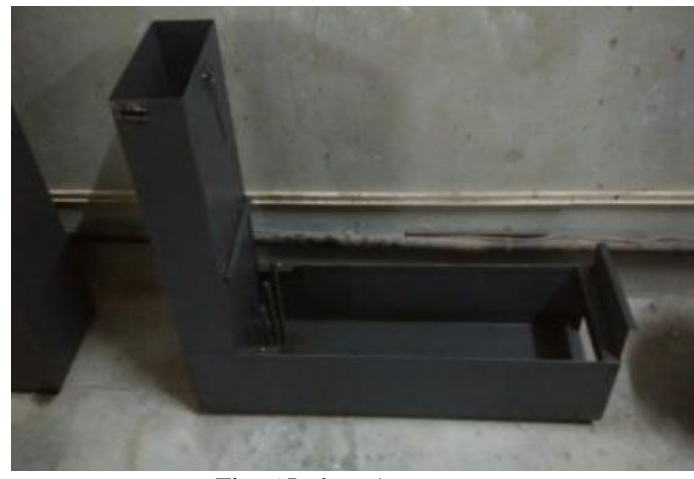

Fig. 6 L- box Apparatus

\begin{tabular}{|c|c|c|c|c|c|c|}
\hline \multicolumn{7}{|c|}{ TABLE 5 VARIOUS TEST PROPORTIONS } \\
\hline $\begin{array}{l}\text { Grade of } \\
\text { Concrete }\end{array}$ & $\begin{array}{c}\text { Mix proportion } \\
\text { No }\end{array}$ & $\begin{array}{c}\text { Cement } \\
\%\end{array}$ & $\begin{array}{c}\text { Perlite } \\
\text { Powder } \\
\text { (\% Replacement } \\
\text { of Cement } \\
\text { Content) }\end{array}$ & $\begin{array}{l}\text { M-Sand } \\
(\%)\end{array}$ & $\begin{array}{l}\text { CA } \\
(\%)\end{array}$ & $\begin{array}{cl} & \text { vermiculite } \\
\text { (\% } & \text { Replacement of } \\
& \text { M-Sand })\end{array}$ \\
\hline \multirow{16}{*}{ M 40} & 1 & 100 & 0 & 100 & 100 & 0 \\
\hline & 2 & 95 & 5 & 100 & 100 & 0 \\
\hline & 3 & 90 & 10 & 100 & 100 & 0 \\
\hline & 4 & 85 & 15 & 100 & 100 & 0 \\
\hline & 5 & 100 & 0 & 95 & 100 & 5 \\
\hline & 6 & 95 & 5 & 95 & 100 & 5 \\
\hline & 7 & 90 & 10 & 95 & 100 & 5 \\
\hline & 8 & 85 & 15 & 95 & 100 & 5 \\
\hline & 9 & 100 & 0 & 90 & 100 & 10 \\
\hline & 10 & 95 & 5 & 90 & 100 & 10 \\
\hline & 11 & 90 & 10 & 90 & 100 & 10 \\
\hline & 12 & 85 & 15 & 90 & 100 & 10 \\
\hline & 13 & 100 & 0 & 85 & 100 & 15 \\
\hline & 14 & 95 & 5 & 85 & 100 & 15 \\
\hline & 15 & 90 & 10 & 85 & 100 & 15 \\
\hline & 16 & 85 & 15 & 85 & 100 & 15 \\
\hline
\end{tabular}




\section{IV)TEST RESUT}

\begin{tabular}{|c|c|c|c|c|c|c|c|c|c|}
\hline \multicolumn{10}{|c|}{ TABLE 6 RESULTS OBTAINED } \\
\hline $\begin{array}{l}\text { SI. } \\
\text { No }\end{array}$ & $\begin{array}{l}\text { Perlite } \\
\text { powder } \\
\text { replaceme } \\
\text { nt }(\%)\end{array}$ & $\begin{array}{l}\text { Vermiculite } \\
\text { replacement } \\
(\%)\end{array}$ & $\begin{array}{l}\text { Slump } \\
\text { Flow } \\
(\mathbf{m m})\end{array}$ & $\begin{array}{l}\mathbf{T}_{50} \text { Slump } \\
\text { Flow (sec) }\end{array}$ & $\begin{array}{l}\text { J- Ring } \\
(\mathbf{m m})\end{array}$ & $\begin{array}{l}\text { L-Box } \\
(\mathbf{m m})\end{array}$ & $\begin{array}{l}\mathrm{U}-\mathbf{B o x} \\
(\mathbf{m m})\end{array}$ & $\begin{array}{l}\text { V- funnelV-funnel at } \\
\text { (sec) }\end{array}$ & $\underset{(\mathrm{sec})}{\mathbf{T}_{5} \text { minutes }}$ \\
\hline 1 & 0 & 0 & 789 & 3 & 619 & 0.998 & 21 & 5.7 & 8.1 \\
\hline 3 & 10 & 0 & 769 & 5.25 & 590 & 0.932 & 11 & 6.7 & 9.2 \\
\hline 4 & 15 & 0 & 745 & 5.4 & 575 & 0.888 & 9 & 7.1 & 9.9 \\
\hline 5 & 0 & 5 & 715 & 3.5 & 610 & 0.987 & 19 & 5.8 & 8.3 \\
\hline 6 & 5 & 5 & 707 & 4.7 & 595 & 0.949 & 12 & 6.2 & 9.0 \\
\hline 10 & 5 & 10 & 675 & 5.3 & 590 & 0.928 & 9 & 6.6 & 9.2 \\
\hline 11 & 10 & 10 & 664 & 5.5 & 582 & 0.904 & 7 & 6.9 & 9.7 \\
\hline 12 & 15 & 10 & 656 & 6.1 & 573 & 0.876 & 6 & 7.6 & 10.8 \\
\hline 13 & 0 & 15 & 652 & 5.1 & 602 & 0.948 & 14 & 6.1 & 8.8 \\
\hline 14 & 5 & 15 & 648 & 5.9 & 585 & 0.915 & 8 & 6.8 & 9.5 \\
\hline 15 & 10 & 15 & 637 & 6.3 & 577 & 0.887 & 5 & 7.2 & 10.4 \\
\hline 16 & 15 & 15 & 632 & 7.1 & 569 & 0.838 & 3 & 7.9 & 11.2 \\
\hline
\end{tabular}

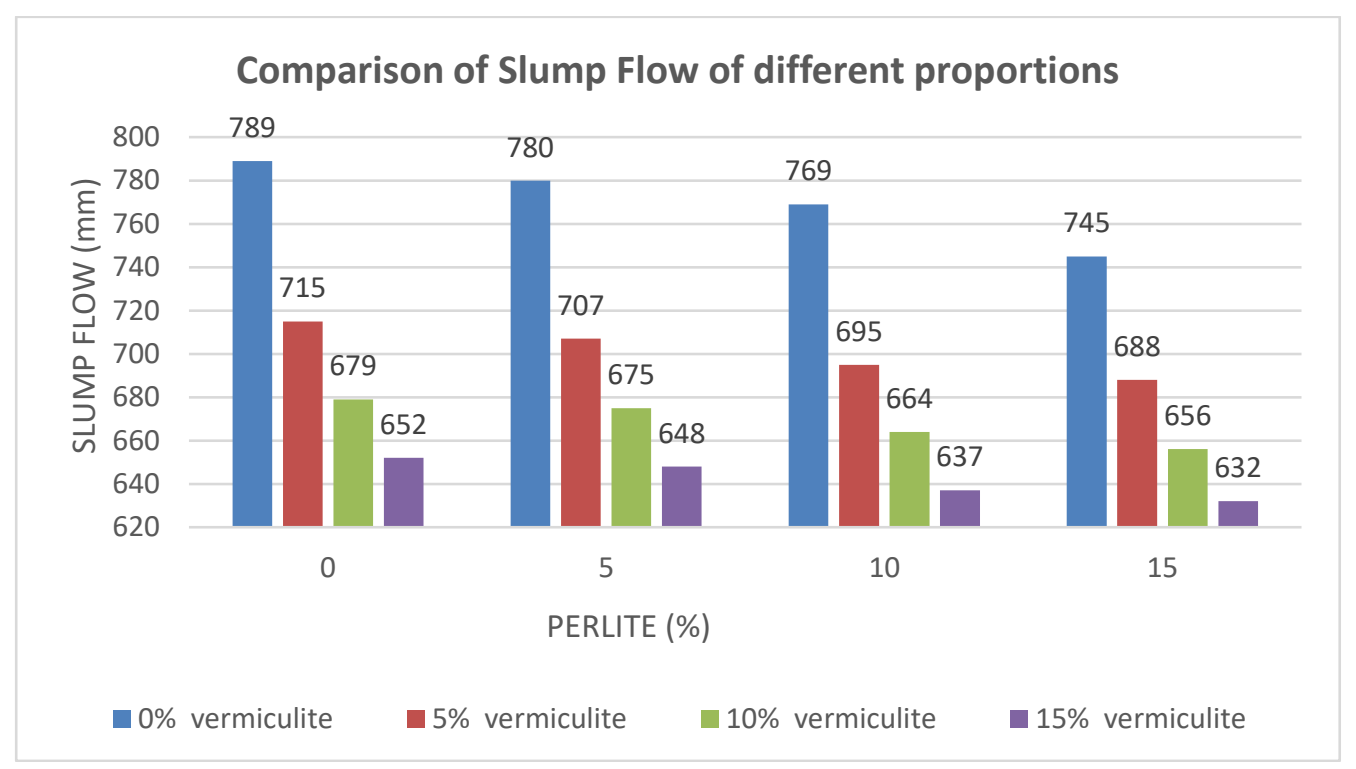

Fig. 7 Comparison of Slump Flow Test of different proportions 


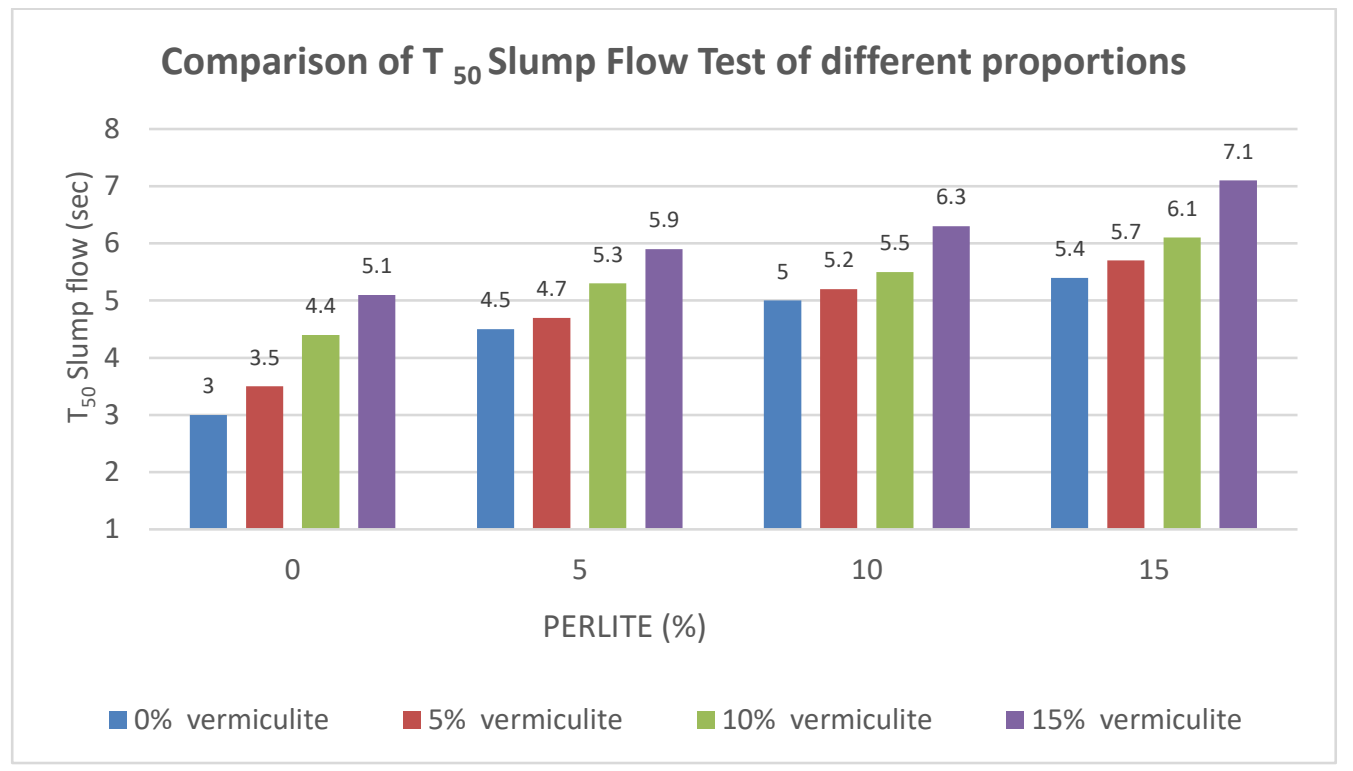

Fig. 8 Comparison of $\mathrm{T}_{50}$ Slump Flow Test of different proportions

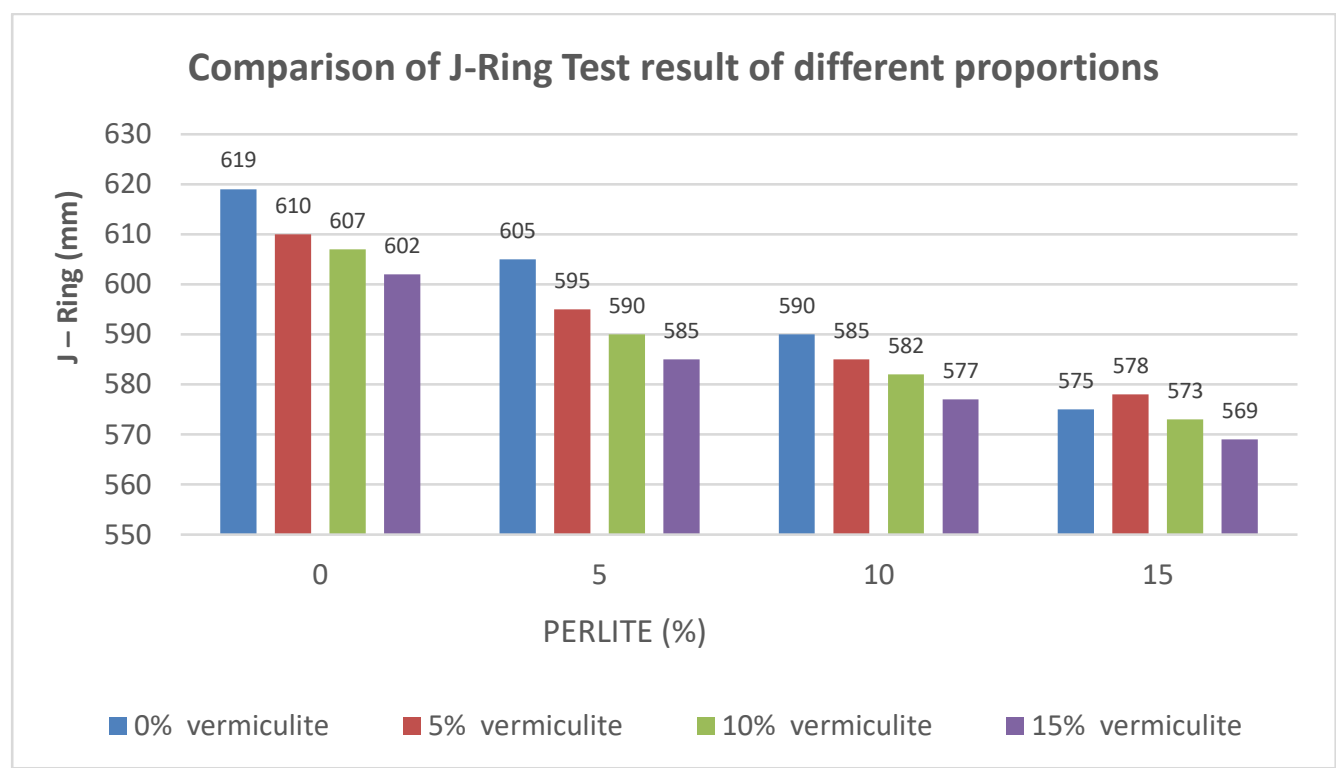

Fig. 9 Comparison of J-Ring Test result of different proportions

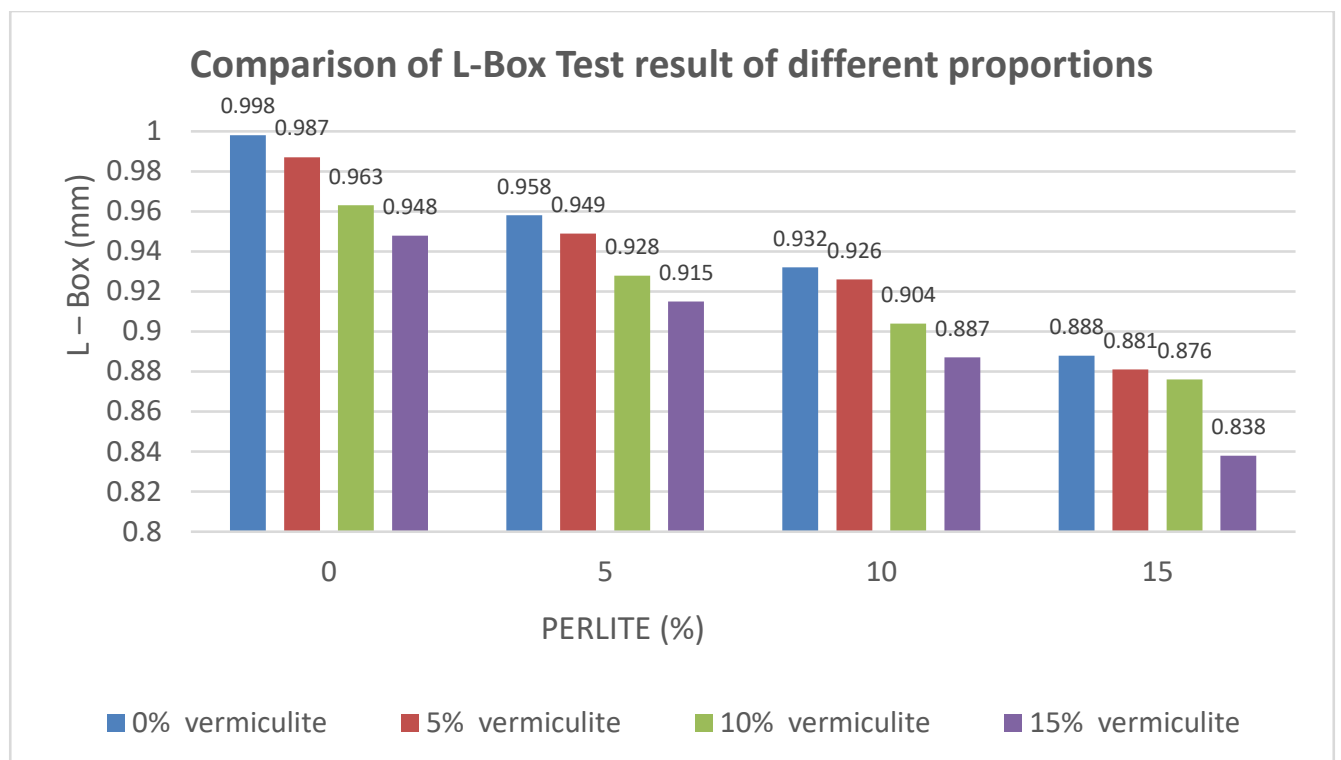

Fig. 10 Comparison of L-Box Test result of different proportions 


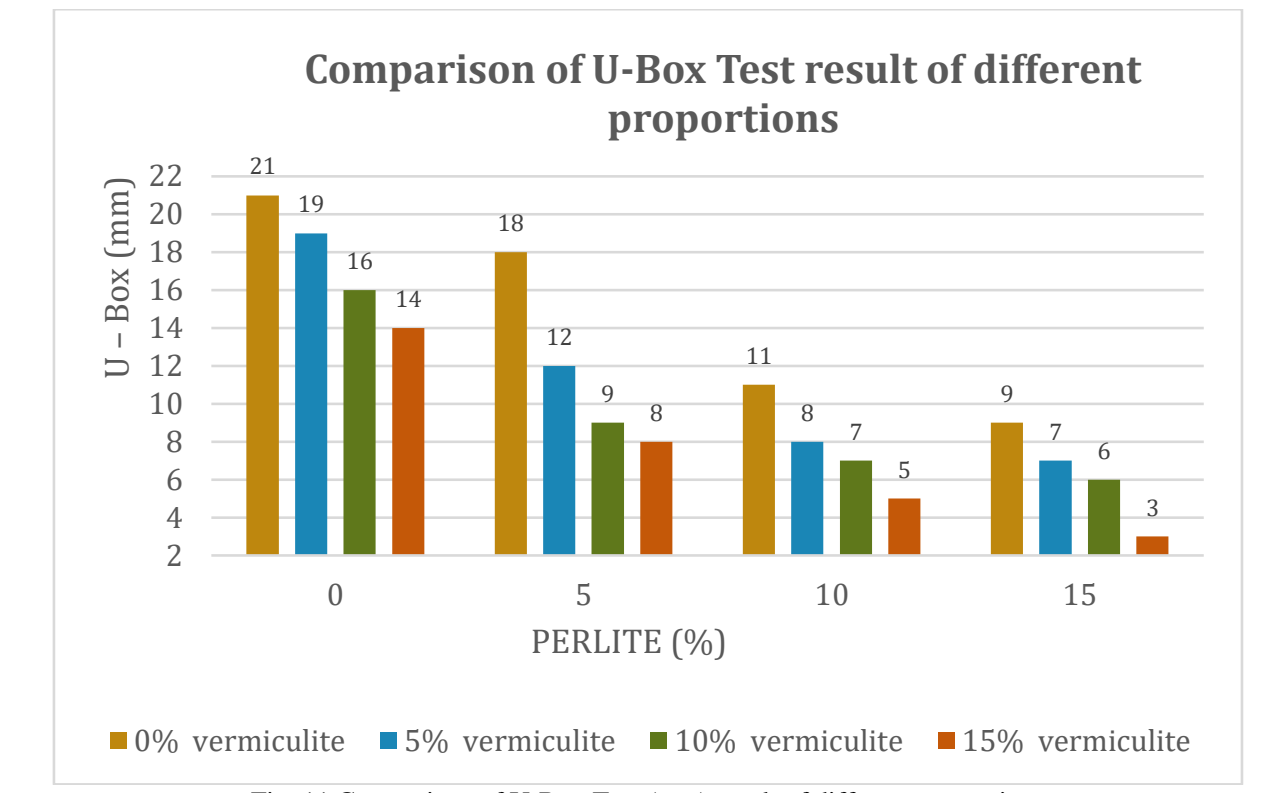

Fig. 11 Comparison of U-Box Test (mm) result of different proportions

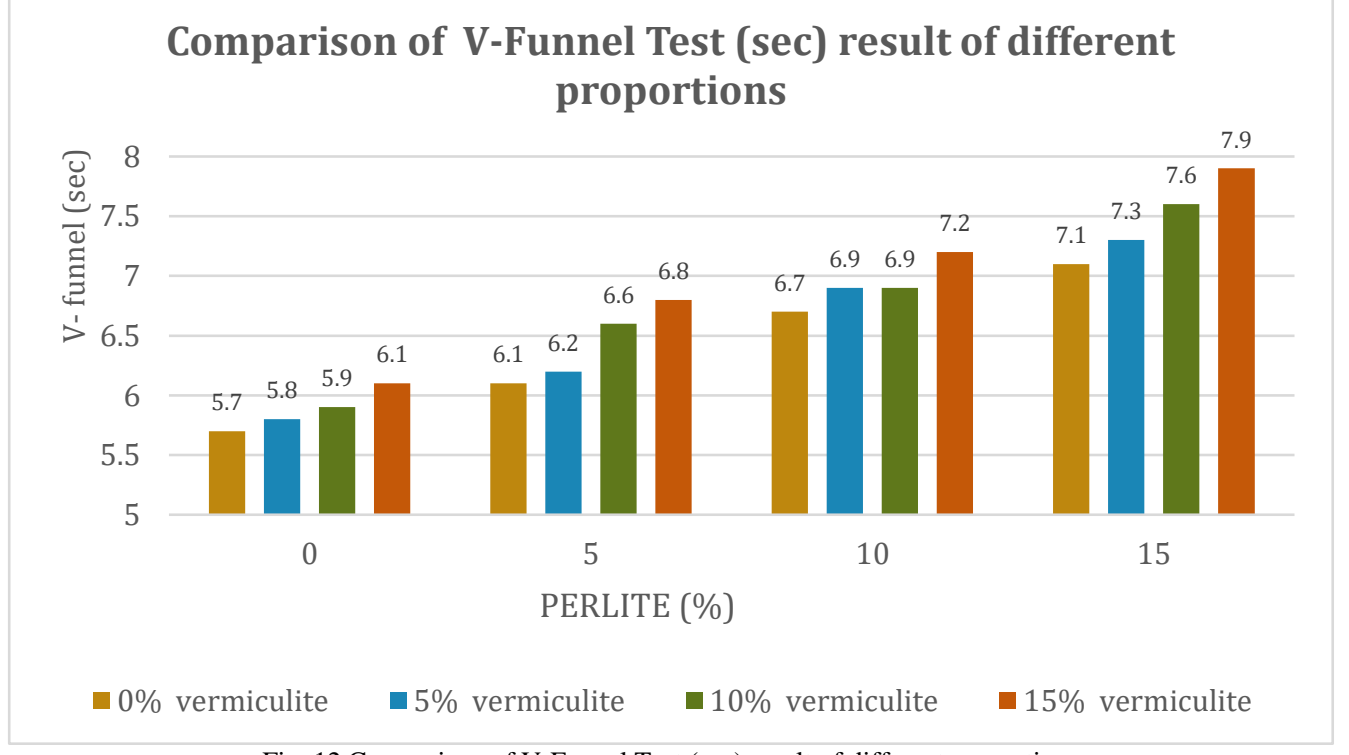

Fig. 12 Comparison of V-Funnel Test (sec) result of different proportions

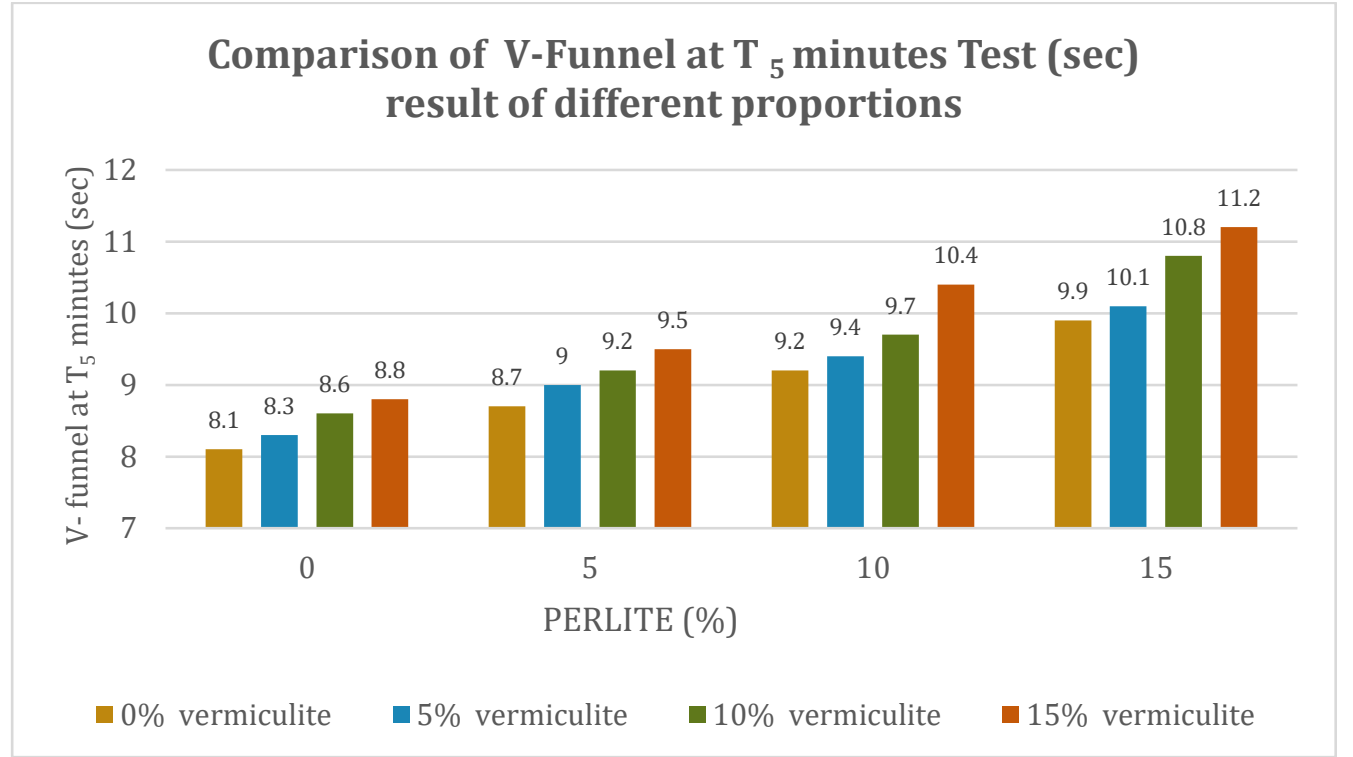

Fig. 13 Comparison of V-Funnelat $\mathrm{T}_{5}$ minutes Test (sec) result of different proportions 


\section{CONCLUSION}

The flow ability is maximum when the percentage of perlite powder added in concrete is minimum. The perlite content is inversely proportional to flow ability of self compacting concrete. The increase in addition of vermiculite causes bleeding and segregation in concrete i.e., the vermiculite does not mix well with water in concrete mix. Super plasticizer acts as a governing agent for setting time of concrete. If $2 \%$ super plasticizer of cement content is added, the concrete sets within 5 minutes. Perlite powder reduces the workability when added in large amount. Cement replacement with perlite powder offers a workability same as that of non-cement replaced concrete and the cement content up to $15 \%$ can be reduced. Since vermiculite, an industrial waste perlite powder is used, an economic product is obtained which is cheaper than conventional SCC. From the experimental investigations, In this project work experiments were carried out for the percentages of perlite added by weight to replace cement by weight $0,5 \%, 10 \%$ and $15 \%$, and vermiculite added by weight to replace fine aggregate by weight were $0,5 \%, 10 \%$ and $15 \%$ in self compacting concrete. The addition of vermiculite resulted in affect the flow parameters in SCC as that of conventional selfcompacting concrete. Optimum water/powder ratio was chosen as 0.35 by weight, the ratio greatly beyond or less than this may cause segregation and blocking tendency in selfcompacting concrete mix.

\section{REFERENCES}

[1] EFNARC, "Specification and Guidelines for Self - Compacting Concrete", February 2002.

[2] Subramanian. S and Chattopadhyay," Mix porportioning of Self Compacting Concrete", 2002.

[3] Hajime Okamura and Masahiro Ouchi on "Self Compacting Concrete", March 2003.

[4] Ravindrarajah, R., Siladyi, D., Adamopoulos, B,“ Development of high strength self-compacting concrete with reduced segregation potential", RILEM publications, August 2003.

[5] Vengala. J, Sudharshan M.S and Ranganath R.V, "Experimental study for obtaining SCC", 2003.
[6] Okamura.H, "Development of Self- Compacting Concrete", ACI Fall convention, New Orleans, 2004.

[7] Frances Yang on "Self Consolidating Concrete", March 2004

[8] Das D, Gupta V K and Kaushik S K on "Effect of maximum Size and Volume of Coarse Aggregate on properties of SCC", May 2006.

[9] Khaleella O.R, Al-Mishhadani S.A, Abdul Razakh," Effect of coarse aggregate on fresh concrete and hardened properties of SCC," 2008.

[10] ZoranGrdić, Iva Despotović, GordanaTopličićĆurčić," Properties of Self Compacting Concrete with different types of additives", 2009.

[11] Indian Standards on "Recommended guidelines for Concrete Mix design", 2009.

[12] Krishna Murthy.N, Narasimha Rao A.V, Ramana Reddy I.V and Vijaya Sekhar Reddy.M on "Mix Design Procedure for SCC", September 2012

[13] Chandra Sekar G, Hemanth Kumar Ch "Effect of fly ash on mechanical properties of light weight vermiculite concrete", (2016).

[14] Mr. M. Gunasekaran (2016), "Study on vermiculite in corporate in mortar", (2016).

[15] M.R.Divya,Prof.M.Rajalingam, Dr.Sunilaa George, "A Study on concrete with replacement of fine aggregate by vermiculite", (2016).

[16] Praveen Kumar E, Manojkumar C, "Experimental study of vermiculite insulated samples with conventional samples in construction industry", (2006).

[17] Gergely A. Sik, Salem G. Nehme, and CecíliaSikLanyi, "The Optimization of the Self-Compacting Concrete (SCC)Production Scheduling-Specially the Effect of the Fine Aggregate" August (2012).

[18] H. Okamura and K. Ozawa, "Mixed-design for self-compacting concrete,". 1995, vol. 25, pp. 107-120.

[19] H. Okamura and M. Ouchi, "Self-compacting Concrete," 2003, vol. 1, no. 1, pp. 5-15.

[20] Abdulkader El Mir, "Utilization of industrial waste perlite powder in self compacting concrete"( 2017).

[21] Sakshi Kabra ,StutiKatara,ashu Rani, “ Characterization and study of perlite" (2013).

[22] Nan Su., Kung-Chung Hsu., and His-Wen Chai., -A simple mix design method for self-compacting concrete, (2001).

[23] Journal of Cement Concrete Research Vol. 31, No. 12, 17991807 pp., Dec(2001).

[24] G. A. Sik, "The effect of the fine aggregate on the mechanical and other properties of the self-compacting concrete (SCC)," November (2011) 